\title{
Fraud inquiry leaves online paper in the ether
}

\section{Geoff Brumfiel}

A nanotechnology paper is spending the summer in a state of electronic limbo, after Science published it online but declined to follow up with the usual publication in print.

The article, which shows evidence for the possibility of combining the hot fields of spintronics and molecular transistors, appeared on Science's website Science Express on 18 April. Science Express papers normally appear in the print journal within "several weeks", according to the website. But after the paper's lead author Jan Hendrik Schön, a researcher at Bell Labs in Murray Hill, New Jersey, was accused of fraud in May, the paper's print publication was delayed. A panel chaired by Malcolm Beasley of Stanford University in California is investigating several papers authored by Schön, who has denied the allegations (see Nature 417, 367-368;2002).

Science would usually send a final version

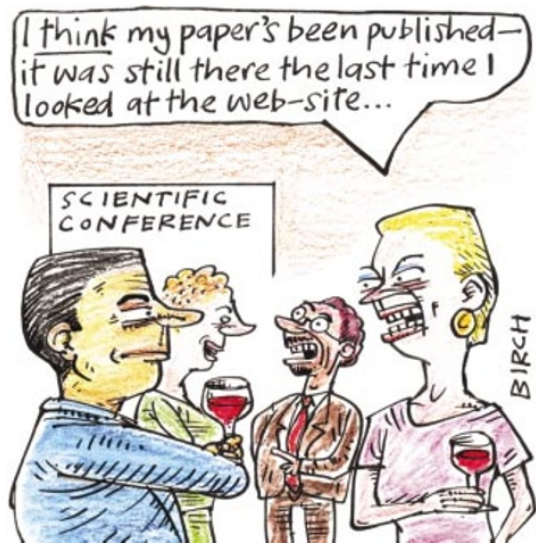

of the paper, edited for print publication, to the authors for approval, but has not done so in this case, says Eldon Emberly of the NEC Research Institute in Princeton, New Jersey,

\section{Pike pests ravage Alaska's salmon}

\section{Rex Dalton, Anchorage}

Alaska - whose vast rivers systems might seem pretty resilient to disturbance - is

learning a harsh lesson about invasive species.

The northern pike (Esox lucius), a fish that already is causing trouble in the rest of the United States, is decimating salmon populations in some rivers in south-central Alaska, researchers in the state believe.

"What was a novelty has turned into a nightmare," says Barry Stratton, a biologist at the State Department of Fish and Game. A growing number of creeks and lakes, once teeming with salmon, are now losing the fish.

Concern about the threat to salmon populations has focused on overfishing and the effect of farmed salmon on natural ones (see Nature 416, 571; 2002). But attention in Alaska is now turning to booming numbers of pike, which eat young salmon in droves before they reach the sea to breed. A 1999 survey by state fisheries managers in Palmer, Alaska, found that $80 \%$ of tested pike had salmon in their stomachs.

Alaskan researchers are now applying for money from the federal government to study the impact of the pike and figure out how best to control or eradicate it.

The northern pike occurs naturally in parts of Alaska, but was only introduced to the salmon-rich south-central area in the $1950 \mathrm{~s}$, when an angler is thought to have brought it to Bulchitna Lake.

In the late 1980s, flooding spread the pike into the streams of the Susitna and Matanuska river basins, biologists say. Now it has spread through both basins -

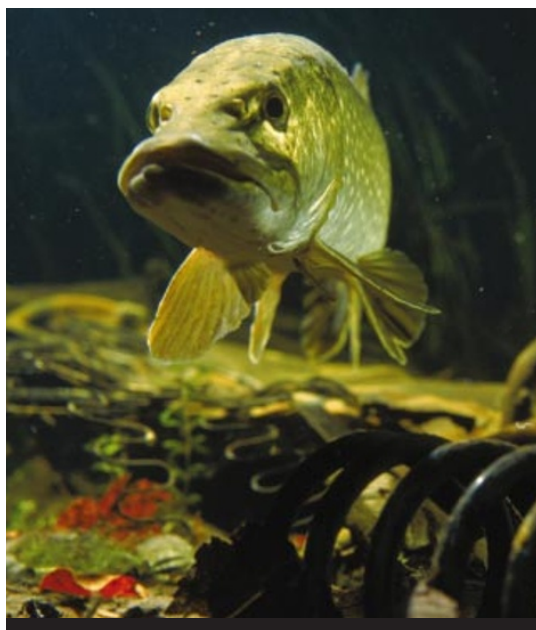

On the prowl: the northern pike's spread has crippled salmon populations in Alaskan rivers.

an area the size of Indiana - and elsewhere. For example, the Kenai Peninsula - an ecologically important region of wilderness and parks - now has pike in at least a dozen lakes and four rivers, all of which are rich in salmon and trout.

Stratton says that Alaskan scientists did not initially understand the seriousness of the invasion. "We now know that when a non-native species shows up we have to jump on it," he says.

But some say that it may be too late to save the salmon. "I'm fatalistic about this," says Mark Gamblin, a biologist in Soldotna. "The genie is out of the bottle. It's going to be real difficult to put back the cork." a co-author of the paper. Science's editor-inchief, Donald Kennedy, says that the hold-up is due to the ongoing investigation into Schön's work. Although Kennedy does not know whether this particular paper is part of the investigation, he says that a decision to assign it a page number will be put on hold until the results of an official inquiry are made public later this summer. "If there is a question about a paper, why would we make the financial investment in printing it? That would just be flat-out silly," says Kennedy.

But some other journal editors fear that the situation will confuse researchers, including those who are considering citing the paper, as it will not be clear whether the work was ever published in Science or not. Because the paper can be cited by others, it needs to be clear what will happen if it never appears on Science's pages, says Martin Bloom, editor of Physical Review Letters, which has considered its online version the "journal of record" since 2001. Bloom adds that his journal would have no choice but to publish an erroneous paper if it had already appeared online. "We would still print it along with a withdrawal," he says, adding that Science "needs to set out a policy".

Others worry that the electronic paper, were it to be retracted, might be lost entirely, potentially undermining the integrity of the scientific record. Clear policies are needed for managing online papers, given the fact that they can be altered or removed from websites, says Paul Ginsparg, a professor of physics and information science at Cornell University in Ithaca, New York, and founder of the Los Alamos preprint server - a service that allows scientists to post papers online before peer review. Although Science has a right not to publish the paper in print, he says, it ought to leave the original paper online, with appropriate updates on its status.

Nature editor Philip Campbell says that this journal's existing policy would prevent such an occurrence. Whereas Science Express papers pass through a final edit before appearing in print, a Nature paper that appears online is considered to be final. Furthermore, authors whose papers are published online are assured that their papers "will be published in print as soon afterwards as space is available". Campbell says that, in a similar set of circumstances, Nature would not reconsider its policy.

Kennedy says that any decision about the precise fate of Schön's paper will have to wait until the investigation is published, but that the work will not be removed from the electronic archive. "The paper isn't in limbo at all — it's published," he says. "I really don't think it's a problem."

But Ginsparg disagrees. "The question is: will that URL on Science Express be there 10-20 years from now?" he asks. 